JURNAL Midwifery Update (MU)

http://jurnalmu.poltekkes-mataram.ac.id/index.php/jurnalmu

e-ISSN: 2684-8511 (Online)

\title{
FAKTOR YANG MEMPENGARUHI KEPUASAN PASIEN TEHADAP TINGKAT PELAYANAN KESEHATAN DI PUSKESMAS KECAMATAN PULAU MERBAU KABUPATEN KEPULAUAN MERANTI
}

\author{
Desi Nindya Kirana ${ }^{1}$, Yunni Safitri ${ }^{2}$, Fitria Haqiqa ${ }^{3}$ \\ 1,2Prodi Sarjana kebidanan dan Profesi Bidan, STIKes Payung Negeri Pekanbaru \\ ${ }^{3}$ Prodi Ilmu Kesehatan Masyarakat, STIKes Payung Negeri Pekanbaru
}

\begin{abstract}
Abstrak
Latar Belakang : Kualitas pelayanan merupakan hal yang terpenting dilakukan perusahaan kepada pelanggan agar tetap loyal menggunakan produk dan pelayanan perusahaan. Kualitas pelayanan menjadi suatu keutamaan yang harus dilakukan perusahaan supaya mampu bertahan dan tetap mendapatkan kepercayaan dari pelanggan. Pelayanan itu sendiri akan dapat terlaksana dengan baik apabila adanya kesadaran dari pegawai dalam memberikan pelayanan serta memenuhi kebutuhan dan kepuasan pelanggan. Prinsip dasar yang perlu dilakukan penyedia jasa adalah memberikan pelayanan jasa yang terbaik, sehingga pelanggan merasa puas. Perasaan puas pelanggan merupakan persepsi yang diterima oleh pelanggan dimana pelayanan yang diterima mendekati kenyataan atau sesuai dengan harapan pelanggan. Tujuan Penelitian : mengetahui pengaruh kepuasan pasien terhadap pelayanan di Puskesmas Kecamatan Pulau Merbau Kabupaten Kepulauan Meranti. Metode : Populasi dalam penelitian ini adalah 2.652 orang. Maka sampel yang diambil adalah sebanyak 93 orang, dengan menggunakan pendapat Lemeshow. Dan teknik pengumpulan data yang digunakan adalah angket dan dokumentasi. Data yang terkumpul dianalisis dengan rumus Regresi Linear Sederhana. Hasil : terdapat pengaruhyang signifikan antara Bukti Fisik dengan Pelayanan kesehatan di Puskesmas Kecamatan Pulau Merbau Kabupaten Kepulauan Meranti dengan nilai R Square 14,9\%, tidak ada pengaruh yang signifikan antaraKehandalan dengan Pelayanan kesehatan di Puskesmas Kecamatan Pulau Merbau Kabupaten Kepulauan Meranti, Bahwa ada pengaruh yang signifikan antara Daya Tanggap dengan Pelayanan kesehatan di Puskesmas Kecamatan Pulau Merbau Kabupaten Kepulauan Meranti dengan nilai R Square 11,2\%, dan tidak ada pengaruh yang signifikan antara Perhatian dengan Pelayanan kesehatan di Puskesmas Kecamatan Pulau Merbau Kabupaten Kepulauan Meranti.
\end{abstract}

Kata kunci : Pengaruh; Kepuasan Pasien; Pelayanan Kesehatan

\section{FACTORS AFFECTING PATIENT SATISFACTION TOWARDS THE LEVEL OF HEALTH SERVICES IN THE HEALTH SERVICE PUSKESMAS, MERBAU ISLAND, MERANTI DISTRICT}

\begin{abstract}
Quality of service is the most important thing the company does to customers in order to remain loyal to using the company's products and services. Service quality is a priority that must be done by the company in order to be able to survive and still get the trust of customers. The service itself will be carried out properly if there is awareness from employees in providing services and meeting customer needs and satisfaction. The basic principle that service providers need to do is to provide the best service, so that customers feel satisfied. Customer satisfaction is a perception received by customers where the service received is close to reality or in accordance with customer expectations. This study aims to determine the effect of patient satisfaction on services at the Puskesmas Pulau Merbau District, Meranti Islands Regency. The population in this study was 2,652 people. So the sample taken is 93 people, using Lemeshow's opinion. And data collection techniques used are questionnaires and documentation. The collected data were analyzed using the Simple Linear Regression formula. After the data was analyzed there was a significant effect between Physical Evidence and health services at the Puskesmas Pulau Merbau District, Meranti Islands Regency with an R Square value of 14.9\%, there was no significant effect between reliability and health services at the Puskesmas Pulau Merbau District, Meranti Islands Regency. there is a significant effect between responsiveness and health services at the Puskesmas Pulau Merbau, Meranti Islands Regency with an R Square value of $11.2 \%$, and there is no significant effect between attention and health services at the Puskesmas Pulau Merbau, Meranti Islands Regency.
\end{abstract}

Keywords: Influence; Patient Satisfaction; Health Services 


\section{Pendahuluan}

Kualitas pelayanan merupakan fungsi antara harapan dan persepsi pelanggan pada lima dimensi kualitas yaitu: Bukti fisik (Tangibles) kemampuan suatu perusahaan dalam menunjukan eksistensinya kepada pihak eksternal, dapat berupa penampilan dan kemampuan sarana dan prasarana fisik perusahaan dan keadaan lingkungan sekitarnya. Bukti fisik diukur dengan indikator kondisi gedung Puskesmas, peralatan pendukung untuk melakukan pemeriksaan pasien, ruang tunggu yang disediakan oleh Puskesmas, penampilan dan kondisi setiap ruangan Puskesmas. Kerapian petugas medis dan non medis dan kebersihan setiap ruangan Puskesmas ${ }^{2}$. Daya Tanggap (Responsivenes) suatu kemampuan untuk membantu dan memberikan pelayanan yang cepat dan tepat kepada pelanggannya ${ }^{3}$. Daya tanggap diukur dengan indikator kesigapan Puskesmas dalam menangani keluhan pasien, tanggapan dari Puskesmas terhadap saran dari para pasien, responden kecepatan dari Puskesmas terhadap setiap keinginan pasien. Keandalan (Reliability) kemampuan memberikan pelayanan yang sesuai secara akurat dan terpercaya, sikap simpatik dan dengan akurasi yang tinggi kepada para pasien. Keanadalan di ukur dengan tindakan pelayanan yang akurat oleh tenaga medis Puskesmas, profesionalisme dalam menangani keluhan pasien oleh para tenaga medis Puskesmas, melayani dengan baik dan ramah saat melakukan pengobatan dan perawatan, memberikan pelayanan dengan tepat dan benar sesuai dengan prosedur yang ditetapkan dalam dalam memberikan pelayanan selalu sesuai dengan jadwal yang telah ditetapkan ${ }^{2}$.

Perhatian (empaty) kemampuan Puskesmas untuk memberikan perhatian yang tulus terhadap semua pasien. Perhatian diukur dengan indikator pelayanan, keramahan yang sama tanpa memandang status pasien Kepuasan Konsumen Bahwa kepuasan konsumen merupakan evaluasi dimana alternatif yang dipilih sekurang-kurangnya sama atau melampaui. Sedangkan ketidakpuasan konsumen timbul apabila hasilnya tidak memenuhi harapan. Kepuasan konsumen tersebut diukur dengan indikator pelayanan medis, fasilitias kesehatan dan lokasi Puskesmas, Selain itu, persepsi pelanggan tentang keuntungan menggunakan kualitas pelayanan akan berhubungan dengan kepuasan pelanggan secara keseluruhan dan pada gilirannya mereka mempunyai niat atau minat untuk melakukan pembelian berulang dan kesediaan untuk merekomendasikan layanan kepada orang lain ${ }^{4}$.

Pelayanan dikatakan berkualitas atau memuaskan bila pelayanan tersebut dapat memenuhi kebutuhan dan harapan masyarakat. Apabila masyarakat tidak puas terhadap suatu pelayanan yang disediakan maka pelayanan tersebut dapat dipastikan tidak berkualitas atau tidak efisien. Pelayanan publik atau pelayanan umum dapat didefinisikan sebagai segala bentuk jasa pelayanan, baik dalam bentuk barang publik maupun jasa publik yang pada prinsipnya menjadi tanggungjawab dan dilaksanakan oleh instansi pemerintah di pusat, di daerah dan di lingkungan Badan Usaha Milik Negara atau Badan Usaha Milik Daerah, dalam upaya pemenuhan kebutuhan masyarakat maupun dalam rangka pelaksanaan ketentuan peraturan perundang - undangan ${ }^{5}$

Pemerintah Daerah wajib memenuhi mutu pelayanan setiap jenis pelayanan dasar pada SPM bidang Kesehatan. Mutu pelayanan setiap jenis pelayanan dasar pada SPM bidang Kesehatan yang terdiri atas, standar jumlah dan kualitas barang dan jasa, standar jumlah dan kualitas personel atau sumber daya manusia kesehatan dan petunjuk teknis atau tata cara pemenuhan standar ${ }^{6}$. Capaian kinerja Pemerintah Daerah dalam pemenuhan mutu pelayanan setiap jenis pelayanan dasar pada SPM Kesehatan harus $100 \%$ (seratus persen). Dari pernyataan tersebut peneliti makin tertarik melakukan penelitian ini, karna ingin mengetahui apakah mutu pelayanan sudah tercapai sesuai dengan keinginan dan cita-cita negara sesuai dengan undang-undang kesehatan no 4 tahun 2019.

Salah satu keluhan yang sering terdengar dari masyarakat yang berhubungan dengan aparatur pemerintah adalah selain berbelit-belit akibat birokrasi yang kaku, perilaku oknum aparatur yang kadang kala kurang bersahabat, juga kinerja pegawai dalam memberikan pelayanan dalam hal ini ketepatan waktu dalam memberikan pelayanan, kuantitas dan kualitas pelayanan yang masih sangat 
rendah. Rendahnya kinerja pelayanan akan membangun citra buruk pada Puskesmas, dimana pasien yang merasa tidak puas akan menceritakan kepada rekan- rekannya. Begitu juga sebaliknya, semakin tinggi kinerja pelayanan yang diberikan akan menjadi nilai plus bagi Puskesmas, pasien dikatakan puas jika apa yang mereka harapkan sesuai dengan apa yang mereka dapatkan. Dalam hal ini pasien akan merasa puas terhadap pelayanan yang diberikan oleh Puskesmas. Puskesmas dapat mengetahui kinerja pelayanan dari para pasien melalui umpan balik yang diberikan pasien kepada Puskesmas tersebut sehingga dapat menjadi masukan untuk peningkatan kinerja pelayanan ${ }^{7}$

Kepuasan pasien didefinisikan sebagai respon pelanggan terhadap ketidak sesuaian antara tingkat kepentingan sebelumnya dan kinerja aktual yang dirasakannya setelah pemakaian. Kepuasan pasien/pelanggan adalah inti dari pemasaran yang berorientasi kepada pasien/pelanggan. Pelayanan yang memuaskan dan berkualitas akan membentuk loyalitas pasien/pelanggan, dan kepuasan sangat erat hubungannya dengan "word of mouth", maka pelayanan yang memuaskan tersebut juga akan mendatangkan pelanggan baru. Efek selanjutnya akan berlanjut pada proses terbentuknya citra Puskesmas yang meningkat. Hal ini dikarenakan kondisi persaingan yang sangat ketat. Maka setiap Puskesmas akan berusaha untuk menempatkan dirinya pada posisi sebaik mungkin dimata pasien/pelanggannya agar dapat dipercaya untuk memenuhi kebutuhannya dalam bidang kesehatan. Begitu juga sebaliknya jika pasien tidak dapat pelayanan yang di inginkan maka akan megakibatkan menurun nya jumlah kunjungan ${ }^{8}$

Kepuasan pasien tergantung pada kulitas pelayanan. Pelayanan adalah semua upaya yang dilakukan karyawan untuk memenuhi keinginan pelanggannya dengan jasa yang akan diberikan. Suatu pelayanan dikatakan baik oleh pasien, ditentukan oleh kenyataan apakah jasa yang diberikan bisa memenuhi kebutuhan pasien, dengan menggunakan persepsi pasien tentang pelayanan yang diterima (memuaskan atau mengecewakan, juga termasuk lamanya waktu pelayanan). Kepuasan dimulai dari penerimaan terhadap pasien dari pertama kali datang, sampai pasien meninggalkan rumah sakit. Pelayanan dibentuk berdasarkan 5 prinsip Service Quality yaitu kecepatan, ketepatan, keramahan dan kenyamanan layanan ${ }^{9}$

Di dukung dengan penelitian ${ }^{3}$ tentang menurunnya kunjungan di rumah sakit berdasarkan service quality yaitu Pelayanan yang diharapkan pasien masih jauh lebih tinggi dari yang di dapatkan, komunikasi eksternal pihak rumah sakit kepada pasien masih tergolong lebih rendah jika dibandingkan dengan proses penyampaian pelayanan kepada pasien, harapan pasien masih jauh lebih tinggi jika dibandingkan dengan pelayanan yang diterima pasien.

Dari pernyataan di atas dapat disimpulkan meningkatnya jumlah pasien ke luar negeri di karnakan tingginya harapan pasien terhadap kualitas pelayanan, yang kita ketahui rumah sakit di luar negeri memang lebih mengutamakan service quality ke semua pasiennya.

Berdasarkan penelitian ${ }^{3}$ yang di lakukan di Puskesmas Siak Hulu II dari hasil penelitiannya Poli Umum masih belum memenuhi kepuasan pasien di dalam sarana prasarana dan kehandalan petugas dalam memberikan apa yang ia janjikan. Berdasarkan penelitian ini ternyata di Riau sendiri masih ada Puskesmas yang masih kurang mutu pelayanannya.

Berdasarkan data yang di dapatkan dari Dinas Kesehatan Kabupaten Meranti jumlah kunjungan pasien dari 10 Puskesmas di Kabupaten Meranti ada 5 Puskesmas yang mengalami penurunan jumlah kunjungan pasien diantaranya, Puskesmas Selat panjang mengalami penurunan sebanyak 1,6\%, Puskesmas Alahair mengalami penurunan sebanyak 8,2\%, Puskesmas Tanjung Samak mengalami penurunan 2,1\% , Puskesmas Pulau Merbau mengalami penurunan 10,32\% dan Puskesmas Teluk Belitung mengalami penurunan sebanyak $10,9 \%$, dari data tersebut maka penulis mengangkat masalah tertinggi dari penurunan pasien yaitu di Puskesmas Pulau Merbau sebanyak 10,32\%. 


\section{Metode}

Penelitian ini menggunakan pendekatan kuantitatif dan jenis penelitian korelasi. Penelitianmetode kuantitatif ini dapat diartikan sebagai metode penelitian yang berlandaskan pada filsafatpositivisme, digunakan untuk meneliti populasi atau sampel tertentu. Polulasi penelitian ini adalah jumlah kunjungan terakhir di Puskesmas Pulau Merbau tahun 2020 yaitu 2.652. penelitian ini dilakukan dari bulan Januari 2020 sampai dengan bulan juni 2020. Teknik pengumpulan data dilakukan dengan angket (kuesioner) cara mengajukan pertanyaan tertulis untuk dijawab secara tertulis pula oleh responden. Angket merupakan kumpulan pertanyaan-pertanyaan yang tertulis yang digunakan untuk memperoleh informasi dari responden tentang diri pribadi atau hal-hal yang iaketahui. angket (kuesioner). Pengumpulan data menggunakan instrument penelitian, analisis data bersifat kuantitatif atau statistik. Dalam penelitian ini untuk menganalisis mutu pelayanan terhadap kepuasan pasien di puskesmas, penelitian ini di lakukan dengan mencari informasi mendalam tentang kepuasan pasien terhadap pelayanan ${ }^{9}$

\section{Hasil dan Pembahasan}

Faktor-faktor yang Mempengaruhi Kepuasan Pasien terhadap Tingkat Pelayanan Kesehatan di Puskesmas Kecamatan Pulau Merbau Kabupaten Kepulauan Meranti

Pengujian hipotesis penelitian dilakukan dengan menggunakan analisis regresi linear sederhana. Analisis ini digunakan untuk mengetahui pengaruh variabel dependen dengan variabel independen, apakah variabel independen berhubungan positif atau negatif dan untuk memprediksi nilai dari variabel dependen apakah mengalami kenaikan atau penurunan. Untuk mengetahui hasil pengujian data dengan menggunakan regresi linear sederhana, peneliti menggunakan bantuan SPSS 20 dengan hasil sebagai berikut:

Tabel 1 Pengaruh Tangibles (Bukti fisik) terhadap Pelayanan Kesehatan Coefficients $^{\mathrm{a}}$

\begin{tabular}{|c|c|c|c|c|c|}
\hline \multirow[t]{2}{*}{ Model } & \multicolumn{2}{|c|}{$\begin{array}{c}\text { Unstandardized } \\
\text { Coefficients }\end{array}$} & $\begin{array}{c}\text { Standardized } \\
\text { Coefficients }\end{array}$ & \multirow[t]{2}{*}{$\mathrm{t}$} & \multirow[t]{2}{*}{ Sig. } \\
\hline & B & Std. Error & Beta & & \\
\hline (Constant) & 23,542 & 1,824 & & 12,908 & ,000 \\
\hline Bukti Fisik & ,789 & 198 & ,386 & 3,990 & ,000 \\
\hline
\end{tabular}

a. Dependent Variable: Pelayanan Kesehatan

Berdasarkan tabel Pengaruh Tangibles (Bukti fisik) terhadap Pelayanan Kesehatan nilai signifikansi sebesar $0,000<0,05$ sehingga dapat disimpulkan bahwa variabel $\mathrm{X}_{1}$ (Bukti Fisik) berpengaruh signifikan terhadap variabel Y (Pelayanan Kesehatan) di puskesmas Kecamatan Pulau Merbau Kabupaten Kepulauan Meranti. Dan diperoleh persamaan regresi linear sederhana sebagai berikut:

$\mathrm{Y}=\mathrm{a}+\mathrm{bX}$

$\mathrm{Y}=23,542+0,386 \mathrm{X}$

Dari hasil perhitungan diperoleh $b=0,386$ bertanda positif, ini berarti: Setiap kali variabel $\mathrm{X}_{1}$ (Bukti Fisik) bertambah satu, maka rata-rata variabel Y (Pelayanan Kesehatan) bertambah 0,386. Dengan demikian jika bukti fisik meingkat, maka pelayanan kesehatan akan bertambah 0,386.

Dari tabel di atas menjelaskan bahwa $r$ hitung $(0,386)>r$ tabel (signifikan $1 \%$ adalah 0,2384 ), sehingga 0,386 >0,2384 mengandung arti regresi antara variabel $\mathrm{X}_{1}$ tehadap $\mathrm{Y}$ sangat kuat. dan 
berdasarkan tabel tersebut diperoleh nilai koefisien determinasi ( $R$ Square) sebesar 0,149. Hal ini menunjukkan bahwa pengaruh variabel independen terhadap variabel dependen adalah sebesar $14,9 \%$.

Tabel 2 Pengaruh Reliability (Kehandalan) terhadap Pelayanan Kesehatan Coefficients $^{\mathbf{a}}$

\begin{tabular}{|c|c|c|c|c|c|}
\hline \multirow[t]{2}{*}{ Model } & \multicolumn{2}{|c|}{$\begin{array}{l}\text { Unstandardized } \\
\text { Coefficients }\end{array}$} & $\begin{array}{c}\text { Standardized } \\
\text { Coefficients }\end{array}$ & \multirow[t]{2}{*}{$\mathrm{t}$} & \multirow[t]{2}{*}{ Sig. } \\
\hline & B & Std. Error & Beta & & \\
\hline (Constant) & 28,340 & 2,222 & & 12,752 & ,000 \\
\hline Kehandalan & ,382 & ,363 &, 110 & 1,053 & ,295 \\
\hline
\end{tabular}

a. Dependent Variable: Pelayanan Kesehatan

Berdasarkan data yang diperoleh nilai signifikansi sebesar 0,295>0,05 sehingga dapat disimpulkan bahwa variabel $\mathrm{X}_{2}$ (Kehandalan) tidak berpengaruh yang signifikan terhadap variabel $\mathrm{Y}$ (Pelayanan Kesehatan) di puskesmas Kecamatan Pulau Merbau Kabupaten Kepulauan Meranti.

Tabel 3 Pengaruh Responsivenes (Daya Tanggap) terhadap Pelayanan Kesehatan Coefficients $^{\mathrm{a}}$

\begin{tabular}{|c|c|c|c|c|c|}
\hline \multirow[t]{2}{*}{ Model } & \multicolumn{2}{|c|}{$\begin{array}{c}\text { Unstandardized } \\
\text { Coefficients }\end{array}$} & $\begin{array}{l}\text { Standardized } \\
\text { Coefficients }\end{array}$ & \multirow[t]{2}{*}{$\mathrm{t}$} & \multirow[t]{2}{*}{ Sig. } \\
\hline & B & Std. Error & Beta & & \\
\hline (Constant) & 23,130 & 2,252 & & 10,269 & ,000 \\
\hline Daya Tanggap & 833 & 246 & ,335 & 3,390 & ,001 \\
\hline
\end{tabular}

a. Dependent Variable: Pelayanan Kesehatan

Tabel 4 Nilai Koefisien Pengaruh Responsivenes (Daya Tanggap) terhadap Pelayanan Kesehatan Model Summary

\begin{tabular}{|l|r|r|r|r|}
\hline Model & \multicolumn{1}{|c|}{$\mathrm{R}$} & $\mathrm{R}$ Square & $\begin{array}{c}\text { Adjusted R } \\
\text { Square }\end{array}$ & $\begin{array}{r}\text { Std. Error of } \\
\text { the Estimate }\end{array}$ \\
\hline 1 &, $335^{\mathrm{a}}$ &, 112 &, 102 & 4,01422 \\
\hline
\end{tabular}

a. Predictors: (Constant), Daya Tangkap

Berdasarkan tabel Pengaruh Responsivenes (Daya Tanggap) terhadap Pelayanan Kesehatan nilai signifikansi sebesar 0,001 $<0,05$ sehingga dapat disimpulkan bahwa variabel $\mathrm{X}_{3}$ (Daya Tanggap) berpengaruh signifikan terhadap variabel Y (Pelayanan Kesehatan) di puskesmas Kecamatan Pulau Merbau Kabupaten Kepulauan Meranti. Dan diperoleh persamaan regresi linear sederhana sebagai berikut:

$\mathrm{Y}=\mathrm{a}+\mathrm{bX}$

$\mathrm{Y}=23,130+0,335 \mathrm{X}$

Dari hasil perhitungan diperoleh $b=0,335$ bertanda positif, ini berarti: Setiap kali variabel $X_{3}$ (Daya Tanggap) bertambah satu, maka rata-rata variabel Y (Pelayanan Kesehatan) bertambah 0,335. Dengan demikian jika daya tanggap meingkat, maka pelayanan kesehatan akan bertambah 0,335.

Dari tabel di atas menjelaskan bahwa $r$ hitung $(0,335)>r$ tabel (signifikan $1 \%$ adalah 0,2384 ), sehingga 0,335 > 0,2384 mengandung arti regresi antara variabel $\mathrm{X}_{3}$ tehadap $\mathrm{Y}$ sangat kuat. dan berdasarkan tabel tersebut diperoleh nilai koefisien determinasi ( $R$ Square) sebesar 0,112. Hal ini menunjukkan bahwa pengaruh variabel independen terhadap variabel dependen adalah sebesar 11,2\%. 
Tabel 5 Pengaruh Empaty (Perhatian) terhadap Pelayanan Kesehatan Coefficients $^{\mathrm{a}}$

\begin{tabular}{|c|c|c|c|c|c|}
\hline \multirow[t]{2}{*}{ Model } & \multicolumn{2}{|c|}{$\begin{array}{l}\text { Unstandardized } \\
\text { Coefficients }\end{array}$} & $\begin{array}{l}\text { Standardized } \\
\text { Coefficients }\end{array}$ & \multirow[t]{2}{*}{$\mathrm{t}$} & \multirow[t]{2}{*}{ Sig. } \\
\hline & B & Std. Error & Beta & & \\
\hline (Constant) & 29,020 & 1,863 & & 15,576 & ,000 \\
\hline Perhatian & ,265 & 297 & ,093 & ,892 & ,375 \\
\hline
\end{tabular}

a. Dependent Variable: Pelayanan Kesehatan

Berdasarkan data yang diperoleh nilai signifikansi sebesar 0,375>0,05 sehingga dapat disimpulkan bahwa variabel $\mathrm{X}_{4}$ (Perhatian) tidak berpengaruh terhadap variabel $\mathrm{Y}$ (Pelayanan Kesehatan) di puskesmas Kecamatan Pulau Merbau Kabupaten Kepulauan Meranti.

\section{Pengaruh Tangibles (Bukti fisik) terhadap Pelayanan Kesehatan}

Berdasarkan data yang diperoleh Pengaruh Tangibles (Bukti fisik) terhadap Pelayanan Kesehatan nilai signifikansi sebesar $0,000<0,05$ sehingga dapat disimpulkan bahwa variabel $\mathrm{X}_{1}$ (Bukti Fisik) berpengaruh terhadap variabel $\mathrm{Y}$ (Pelayanan Kesehatan) di puskesmas Kecamatan Pulau Merbau Kabupaten Kepulauan Meranti. Dari hasil perhitungan diperoleh $b=0,386$ bertanda positif,ini berarti: Setiap kali variabel $\mathrm{X}_{1}$ (Bukti Fisik) bertambah satu, maka rata-rata variabel Y (Pelayanan Kesehatan) bertambah 0,386. Dengan demikian jika bukti fisik meningkat, maka pelayanan kesehatan akan bertambah 0,386. Dari Nilai Koefisien Korelasi Pengaruh Tangibles (Bukti fisik) terhadap Pelayanan Kesehatan menjelaskan bahwa $r$ hitung $(0,386)>r$ tabel (signifikan $1 \%$ adalah 0,2384 ), sehingga 0,386 $>0,2384$ mengandung arti regresi antara variabel $\mathrm{X}_{1}$ tehadap $\mathrm{Y}$ sangat kuat. Dan berdasarkan data tersebut diperoleh nilai koefisien determinasi ( $R$ Square) sebesar 0,149. Hal ini menunjukkan bahwa pengaruh variabel independen terhadap variabel dependen adalah sebesar 14,9\%.

\section{Pengaruh Reliability (Kehandalan) terhadap Pelayanan Kesehatan}

Berdasarkan data yang diperoleh nilai signifikansi sebesar 0,295>0,05 sehingga dapat disimpulkan bahwa variabel $\mathrm{X}_{2}$ (Kehandalan) tidak berpengaruh terhadap variabel $\mathrm{Y}$ (Pelayanan Kesehatan) di puskesmas Kecamatan Pulau Merbau Kabupaten Kepulauan Meranti.

\section{Pengaruh Responsivenes (Daya Tanggap) terhadap Pelayanan Kesehatan}

Berdasarkan data yang diperoleh Pengaruh Responsivenes (Daya Tanggap) terhadap Pelayanan Kesehatan nilai signifikansi sebesar $0,001<0,05$ sehingga dapat disimpulkan bahwa variabel $\mathrm{X}_{3}$ (Daya Tanggap) berpengaruh terhadap variabel Y (Pelayanan Kesehatan) di puskesmas Kecamatan Pulau Merbau Kabupaten Kepulauan Meranti. Dari hasil perhitungan diperoleh $b=0,335$ bertanda positif, ini berarti: Setiap kali variabel $\mathrm{X}_{3}$ (Daya Tanggap) bertambah satu, maka rata-rata variabel Y (Pelayanan Kesehatan) bertambah 0,335. Dengan demikian jika daya tanggap meningkat, maka pelayanan kesehatan akan bertambah 0,335. Dari Nilai Koefisien Korelasi Pengaruh Responsivenes (Daya Tanggap) terhadap Pelayanan Kesehatan menjelaskan bahwa $\mathrm{r}$ hitung $(0,335)>\mathrm{r}$ tabel (signifikan 1\% adalah 0,2384), sehingga 0,335 > 0,2384 mengandung arti regresi antara variabel $3_{1}$ tehadap $\mathrm{Y}$ sangat kuat. dan berdasarkan data tersebut diperoleh nilai koefisien determinasi ( $R$ Square) sebesar 0,112. Hal ini menunjukkan bahwa pengaruh variabel independen terhadap variabel dependen adalah sebesar 11,2\%. 


\section{Pengaruh Empaty (Perhatian) terhadap Pelayanan Kesehatan}

Berdasarkan data yang diperoleh nilai signifikansi sebesar $0,375>0,05$ sehingga dapat disimpulkan bahwa variabel $\mathrm{X}_{4}$ (Perhatian) tidak berpengaruh terhadap variabel $\mathrm{Y}$ (Pelayanan Kesehatan) di puskesmas Kecamatan Pulau Merbau Kabupaten Kepulauan Meranti.

\section{Kesimpulan}

Bahwa ada pengaruh yang signifikan antara Bukti Fisik dengan Pelayanan kesehatan di Puskesmas Kecamatan Pulau Merbau Kabupaten Kepulauan Meranti dengan nilai $R$ Square 14,9\%

Bahwa tidak ada pengaruh yang signifikan antara Kehandalan dengan Pelayanan kesehatan di Puskesmas Kecamatan Pulau Merbau Kabupaten Kepulauan Meranti, bahwa ada pengaruh yang signifikan antara Daya Tanggap dengan Pelayanan kesehatan di Puskesmas Kecamatan Pulau Merbau Kabupaten Kepulauan Meranti dengan nilai $R$ Square $11,2 \%$.

Bahwa tidak ada pengaruh yang signifikan antara Perhatian dengan Pelayanan kesehatan di Puskesmas Kecamatan Pulau Merbau Kabupaten Kepulauan Meranti.

\section{Daftar Pustaka}

1. Literate S, Indonesia JI. View metadata, citation and similar papers at core.ac.uk. Pengaruh Pengguna Pasta Labu Kuning (Cucurbita Moschata) Untuk Substitusi Tepung Terigu dengan Penambahan Tepung Angkak Dalam Pembuatan Mie Kering

2. Wibisono A, , S. Pengaruh Kualitas Jasa Pelayanan Terhadap Kepuasan Pelanggan. Perform “ J Bisnis Akuntansi." 2016

3. Reno R, Widodo MD. Analisis Mutu Pelayanan Kes. Collab Med J. 2018;1(2):1-9.

4. Masyarakat JK. Analisis Tingkat Kepuasan Pasien Terhadap Kualitas Pelayanan Rawat Jalan Di Puskesmas Duren Dan Puskesmas Bergas Kabupaten Semarang Tahun 2017. J Kesehat Masy. 2017;5(4):33-42.

5. Cynthia Silsilia Tolioso, Chreisye K.F.Mandungi FKK. Hubungan Mutu Pelayanan Kesehatan Dengan Kepuasan Pasien Di Puskesmas Bahu Kota Manado. Kesmas. 2018;7:1-10.

6. Permenkes. Peraturan Menteri Kesehatan Republik Indonesia. 2019:5-10.

7. Di J, Way P, Kota H, Lampung B. Hubungan Mutu Pelayanan Terhadap Tingkat Kepuasan Pasien Rawat. 2018;12(2):92-102.

8. Kuntoro W, Istiono W. Kepuasan Pasien Terhadap Kualitas Pelayanan di Tempat Pendaftaran Pasien Rawat Jalan Puskesmas Kretek Bantul Yogyakarta. E-Journal. 2017;2(1).

9. Anjaryani Diah Wika. Kepuasan Pasien Rawat Inap Terhadap Pelayanan Perawat di RSUD Tugurejo Semarang,Universitas Diponogoro,Semarang. 2009. 